\title{
Late Pleistocene-early Holocene fluvial facies and depositional processes in the Fehmarn Belt, between Germany and Denmark, revealed by high-resolution seismic and lithofacies analysis
}

\author{
BERNHARD NOVAK* and SVANTE BJÖRCK† \\ *Jægersborggade 2, DK-2200, Copenhagen N, Denmark (E-mail: standard.factory@get2net.dk) \\ $\dagger$ Department of Quaternary Geology, University of Lund, Tornav. 13, SE-22363, Lund, Sweden
}

\begin{abstract}
In the narrow offshore border zone between Germany and Denmark, $550 \mathrm{~km}$ of high-density $3 \cdot 5-\mathrm{kHz}$ subbottom seismic reflection profiles were recorded within a $70-\mathrm{km}^{2}$ area in order to reconstruct the seismic stratigraphy of late Pleistocene to early Holocene lacustrine and fluvial environments. Using detailed line drawings, seismic facies analyses and a hierarchy of bounding surfaces, a depositional unit was recognized and subdivided into subunits $4^{\text {a }}$ (oblique-parallel), $4^{\mathrm{b}}$ (mound, oblique-tangential), $4^{\mathrm{c}}$ (sigmoid, oblique), $4^{\mathrm{d}}$ and $4^{\mathrm{e}}$ (shingled and parallel). The base of this seismic facies association defines a wide U-shaped valley with well-defined scours and, in the valley sides, 'steps' are located above deep steep-dipping reflections. Stratigraphic control was available from 32 coring sites (5- to 12 -m-deep vibrocores). Subunit $4^{\text {b }}$ represents coarsening-up silt and sand, and samples from subunit $4^{\mathrm{d}}$ show fining-up fine sand, silt and clay. The seismic facies association is proposed to have formed by a fluvial event of short duration some time in the period between $10 \cdot 3{ }^{14} \mathrm{C}$ ka BP and $9 \cdot 0{ }^{14} \mathrm{C}$ ka BP. Subunits $4^{\mathrm{a}}$ to $4^{\mathrm{e}}$ represent gradually decreasing flow power. A peak flow initiated the fluvial event, after which water discharge and level fell rapidly. Subsequently, the normal background discharge from the Baltic Sea area dominated the flow style. Reflections beneath the 'step'-like valley side with high dip angles are interpreted as faults. This tectonic activity resulted in subsidence in the analysed area and could possibly have influenced the fluvio-dynamic development. The seismic stratigraphic succession reveals a high-resolution record of sediments in this area. In particular, the stepwise uncovering of the morphology of the subunits, preserved in high-resolution seismic facies associations, is proposed as a useful tool in modelling the dynamic development of the near sea-floor environment.
\end{abstract}

Keywords Architectural element, lake drainage event, seismic texture, shallow seismic.

\section{INTRODUCTION}

This paper presents the results of a high-resolution seismic reflection study in the Fehmarn Belt, between Mecklenburg Bay, northern Germany, and Great Belt, southern Denmark, in water depths between 10 and $30 \mathrm{~m}$ (Fig. 1).

Quaternary deposits in the region directly overlie Upper Cretaceous clay and silt and

(c) 2002 International Association of Sedimentologists
Palaeocene/Eocene clay (Ter-Borch, 1987; Danish Ministry of Transport, Bundesministerium für Verkehr, 1996). Since the final retreat of glaciers from the south-western Baltic area, approximately $14 \cdot 0{ }^{14} \mathrm{C}$ ka BP (Mörner, 1969; Lagerlund \& Houmark-Nielsen, 1993), Fehmarn Belt has been characterized by highly variable sedimentary processes and environments. Rapid isostatic rebound dominated after ice recession, resulting 


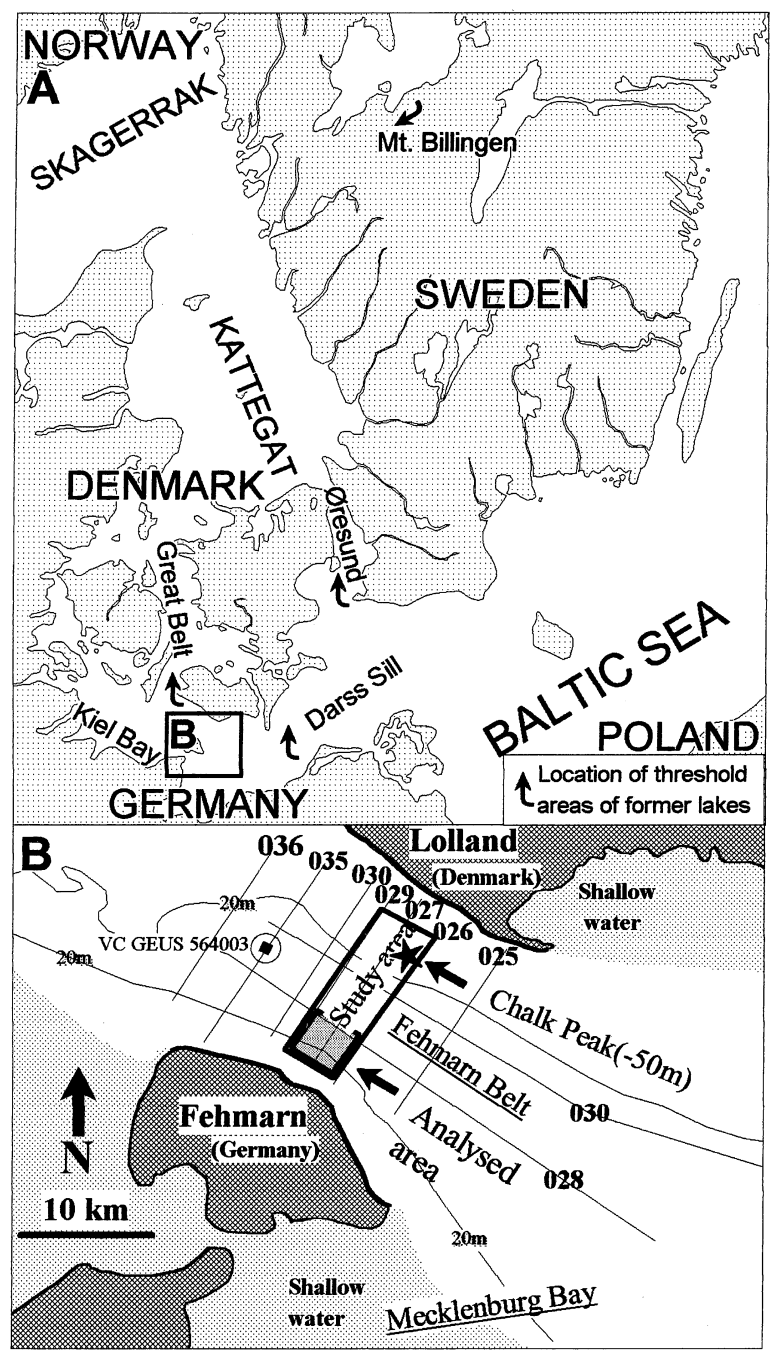

Fig. 1. Location map of the study area, Fehmarn Belt, Mecklenburg Bay and vicinity. (A) Southern Scandinavia with threshold areas indicated. (B) The $-20 \mathrm{~m}$ bathymetric contour line. Bold numbers 004-036 mark a regional seismic grid (GEUS profiles) and vc GEUS 564003 shows the location of a vibrocore and a dated sample. A star within the study area represents a preQuaternary chalk peak.

in three regional highstand lake stages in the Baltic Sea area (Table 1). Differential Fennoscandian uplift in the lake threshold areas; Great Belt, Øresund, Darss Sill and Mt Billingen (Fig. 1), produced a complex drainage history during the early Baltic stages (Björck, 1995). The overflow from the lake to the Kattegat changed position several times over 4000 years (Fig. 1, Table 1), causing the local base-level to have a highly dynamic history.

The main stages of the Baltic Sea area from deglaciation to recent time are: the Baltic Ice Lake BILi (initial) and BILf (final) stages, the Yoldia
Sea (YS), the Ancylus Lake (AL) and, finally, the marine Littorina Sea (LS) (Björck, 1979, 1987, 1995; Björck \& Digerfeld, 1986; Björck \& Möller, 1987; Lundqvist, 1987; Svensson, 1989, 1991). The two stages of the BIL (c. 13.5-11.2 and 11.2$10 \cdot 3{ }^{14} \mathrm{C}$ ka BP) and the AL (c. 9.5-9.0 $\left.{ }^{14} \mathrm{C} \mathrm{ka} \mathrm{BP}\right)$ are represented in seismic reflection records, as well as in sediment records from the region, as three cycles of lake-level highstand to lowstand. The BILf extended to Mecklenburg Bay and Fehmarn Belt and had a shore-level altitude of c. $-20 \mathrm{~m}$ in the area (Fig. 1; Jensen et al., 1997; Bennike \& Jensen, 1998). Björck (1995) concluded that the AL transgression, with a maximum water level above $-20 \mathrm{~m}$ altitude in the southern Baltic region, was caused by isostatic uplift of a threshold area (or sill), Mt Billingen in western Sweden (Fig. 1). Evidence includes transgressive sand, which is found on a prograding wedge in southeastern Mecklenburg Bay (Fig. 1; Bennike \& Jensen, 1998; Jensen et al., 1999) and is believed to have an age of $c .9 \cdot 2{ }^{14} \mathrm{C}$ ka BP. Not much evidence of this stage is recognized west of the Darss Sill (Fig. 1), and some authors consider Mecklenburg Bay to have been unaffected by the AL transgression (Eronen et al., 1990).

After the AL transgression, Bennike \& Jensen (1998) and Jensen et al. (1999) proposed an eastward drainage and a limited ( $5 \mathrm{~m}$ ) water-level lowering in Mecklenburg Bay due to a $-24 \mathrm{~m}$ altitude threshold at the Darss Sill (Fig. 1). In contrast, as the AL transgression was followed by a rapid regression (e.g. Eronen, 1983; Ristaniemi \& Glückert, 1987; Svensson, 1989), Björck (1995) concluded that this event may be explained by the 'Dana River' hypothesis of von Post (1929), which proposed drainage towards the west. A deep and narrow channel $(<1 \mathrm{~km}$ wide) was eroded into the Great Belt (Fig. 1) and, according to Björck (1995), the AL level fell at least $10 \mathrm{~m}$ until it reached recent sea level. Novak \& Björck (1998) claimed to have found the sedimentary unit related to this event in an area north of Great Belt at the southern Kattegat (Fig. 1). Since the late Pleistocene, the isostatic rebound has been surpassed by eustatic sea-level rise in the southwestern part of the Baltic Sea, and the lake and marine transgression sediments are therefore found below present sea level. Lemke et al. (1994, 1997), Lemke \& Kuijpers (1995), Jensen et al. (1996, 1997, 1999), Bennike et al. (1997, 1998) and Bennike \& Jensen (1998) used various methods to determine the environmental history of this part of the Baltic. They focused on environmental dynamics using open-spaced shallow 
Table 1. Timing of the Baltic stages after the main Weichsel glaciation, the drainage style, the drainage direction and the salinity in Fehmarn Belt.

\begin{tabular}{|c|c|c|c|c|}
\hline${ }^{14} \mathrm{C}$ ka BP & Baltic stages & Drainage style & Salinity & Remarks, drainage route (Fig. 1) \\
\hline$<8 \cdot 0$ & Littorina Sea & Non-dammed & Brackish & Connection through GB and Or \\
\hline $9 \cdot 0-8 \cdot 0$ & Ancylus Lake & Non-dammed & Fresh & $\begin{array}{l}\text { Drain towards GB ('Dana River') } \\
\quad \text { or Or (Darss Sill). No consensus }\end{array}$ \\
\hline $9 \cdot 5-9 \cdot 0$ & Ancylus Lake & Threshold & Fresh & $\begin{array}{l}\text { Overflow towards GB or Or. No } \\
\text { consensus }\end{array}$ \\
\hline $10 \cdot 3-9 \cdot 5$ & Yoldia Sea & Non-dammed & Brackish/fresh & $\begin{array}{l}\text { Connection through west } \\
\text { Sweden, Mt B. No marine } \\
\text { indication in Fehmarn Belt }\end{array}$ \\
\hline $10 \cdot 9-10 \cdot 3$ & Baltic Ice Lake (final) & Threshold & Fresh & Or and finally Mt B \\
\hline $11 \cdot 2-10 \cdot 9$ & Baltic Ice Lake (final) & Non-dammed & Fresh & \\
\hline $11 \cdot 8-11 \cdot 2$ & Baltic Ice Lake (initial) & Threshold & Fresh & Mt B \\
\hline $13 \cdot 0-11 \cdot 8$ & Baltic Ice Lake (initial) & Non-dammed & Fresh & Or \\
\hline
\end{tabular}

GB, Great Belt; Or, Øresund; Mt B, Mt Billingen (see Fig. 1 for locations).

seismic reflection methods combined with sequence stratigraphy, diatoms and macrofossil sampling and extensive radiocarbon dating.

The present study shows that high-resolution seismic reflection mapping can reveal the geometry of depositional architecture, which may be a valuable tool for interpreting the highly dynamic late glacial and Holocene environmental changes in the investigated area. This interpretation requires seismic facies analysis based on line drawings of seismic texture, outlining seismic facies associations (Novak \& Björck, 1998; Novak \& Pedersen, 2000; Novak \& Stoker, 2001) and using the concept of depositional architecture sensu Miall $(1985,1988)$. A model showing the gradual development of the depositional archi- tecture, represented in seismic facies, can be useful in predicting sedimentary environments. Such an approach can significantly improve the three-dimensional understanding of depositional changes in a small but complex area.

\section{METHODS}

Danish Ministry of Transport, Bundesministerium für Verkehr (1996) acquired $550 \mathrm{~km}$ of shallow seismic reflection data within an area of $70 \mathrm{~km}^{2}$ (8 $\mathrm{km} \mathrm{km}^{-2}$ mean density; Fig. 2).

A regional open-spaced $(2000 \mathrm{~m})$ shallow seismic grid acquired in 1993 was provided by The Geological Survey of Denmark and Greenland

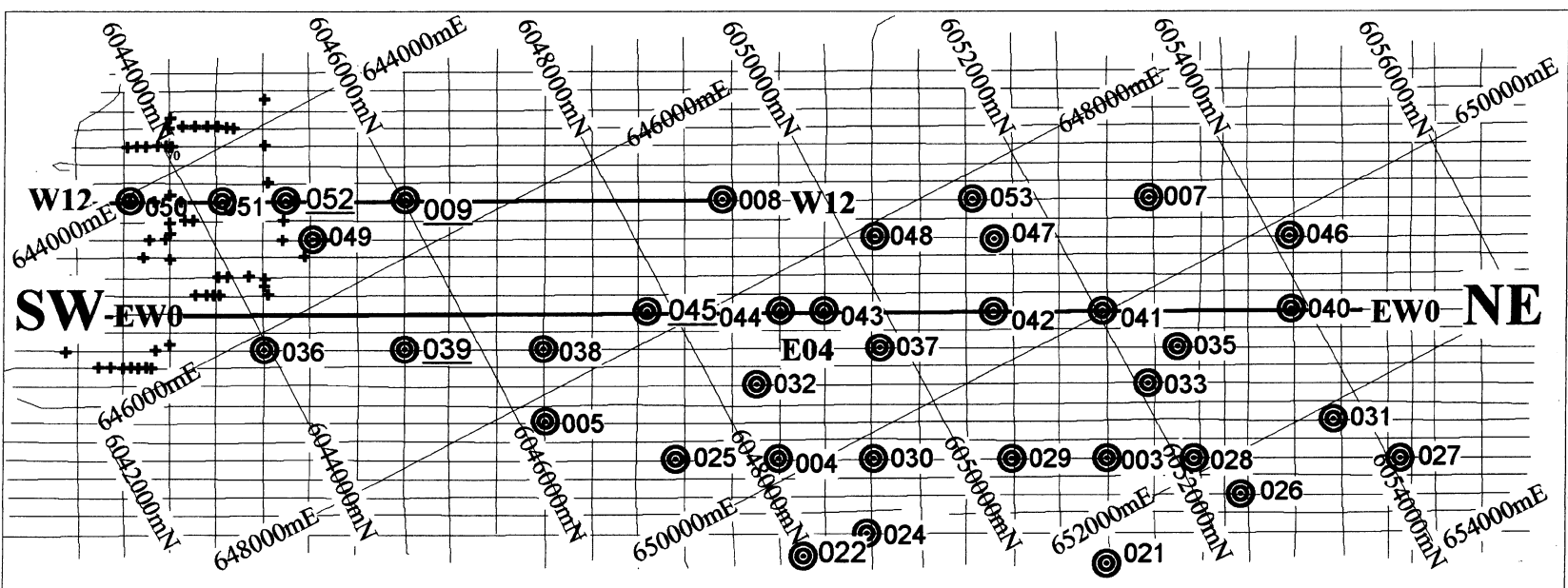

Fig. 2. Seismic grid and vibrocore locations (numbered circles) in the study area shown in Fig. 1. UTM grid spacing is $2 \mathrm{~km}$. Location of interpreted profile examples (Figs 9 and 10) are indicated with bold lines. Crosses indicate the location of observed high dip-angle reflections with an overall north-east dip (Figs 3 and 8-10) and beneath the 'steps' in the south-western escarpment. 
(GEUS) (Fig. 1). The equipment used was a $3 \cdot 5-\mathrm{kHz}$ subbottom profiler (SBP) and a uniboomer (GEUS). The SBP shoot interval was set at $0.125 \mathrm{~s}$, the recording time $0.075 \mathrm{~s}$, and the high-pass filter was set at $2 \cdot 4 \mathrm{kHz}$. A seismic velocity of $1500 \mathrm{~m} \mathrm{~s}^{-1}$ was used for time-to-depth conversion, thus providing minimum estimates of sedimentary unit thickness. Positioning was recorded with a differential geographic position system (DGPS) and with the European Datum (ED) 50 reference.
The seismic profiles have a horizontal/vertical ratio of $1: 10$, and the interpretation involves seismic facies and texture analysis to identify subunit boundaries on seismic profiles. The facies analysis followed the concept of Mitchum et al. (1977). In the first stage of interpretation, detailed line drawings were compiled by highlighting the acoustic texture, here defined as the morphology, length and orientation of the individual reflections. Minor reflections without orientation and perceived seismic noise were
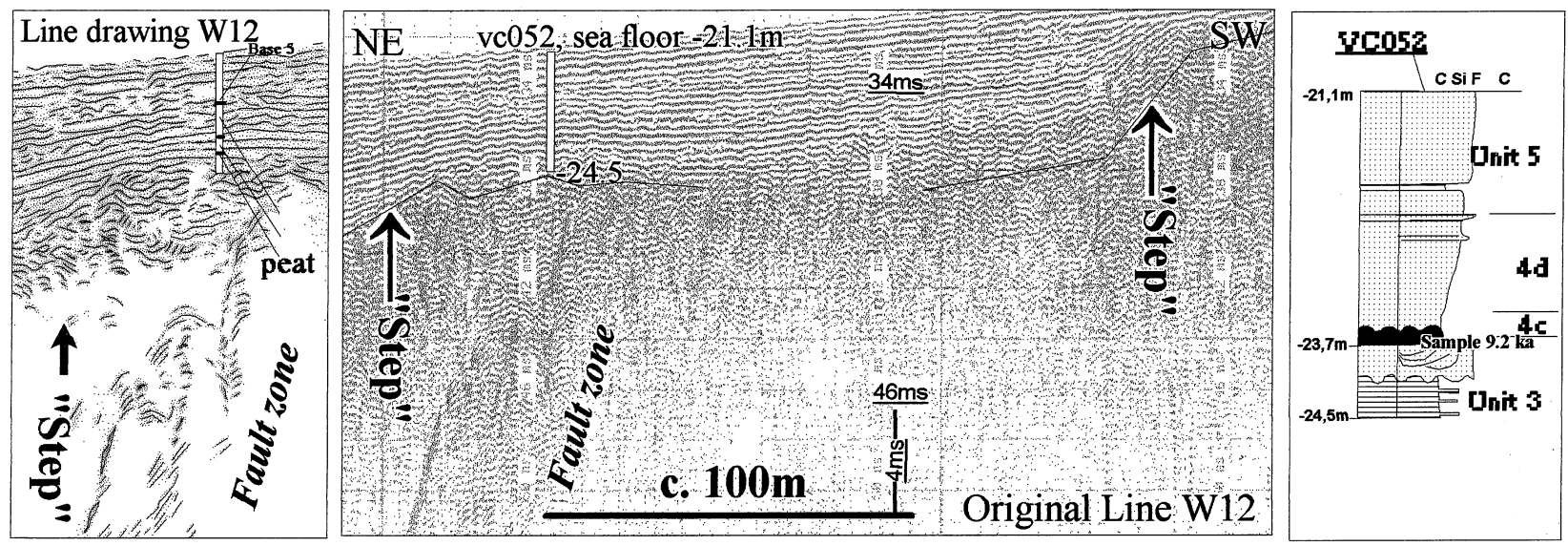

Fig. 3. A $3 \cdot 5-\mathrm{kHz}$ pinger seismic profile (centre) with line drawing (left) and core $\log 052$ (right). The core site is shown on the profile and located in Figs 2, 8 and 11-15. The two-way travel time in ms is labelled on the profile, and the core log shows altitude in $\mathrm{m}$. A fault zone is indicated beneath the step-like escarpment. See Fig. 8 for legend. The peat was dated $c .9 \cdot 2{ }^{14} \mathrm{C} \mathrm{ka} \mathrm{BP.}$

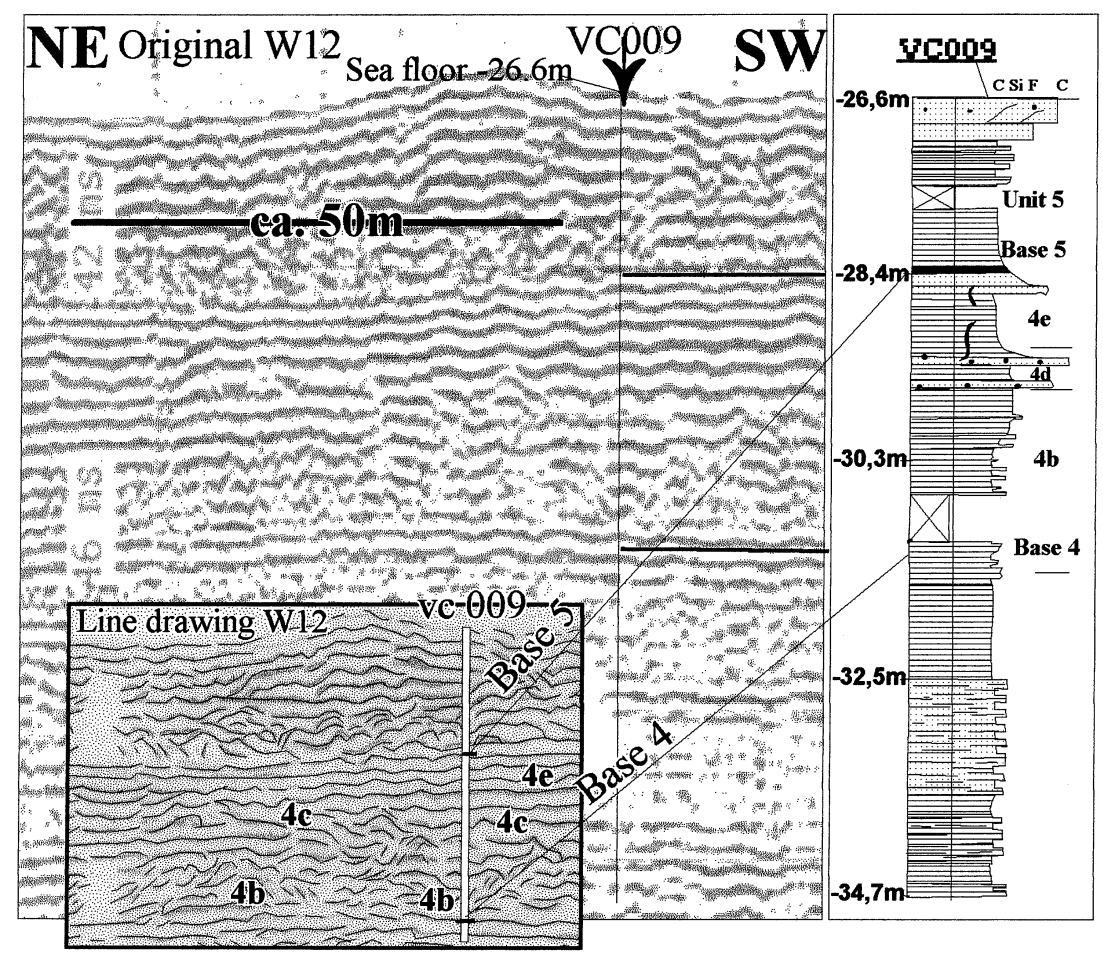

Fig. 4. A $3 \cdot 5-\mathrm{kHz}$ pinger seismic example with line drawing and core log site 009. The core site is indicated on the seismic example and located in Figs 2, 8 and 10. The twoway travel time in ms is labelled on the left side of the profile, and the core log shows altitude in $\mathrm{m}$. Subunits indicated on the line drawing. See Fig. 8 for legend. 
Fig. 5. A $3 \cdot 5-\mathrm{kHz}$ pinger seismic profile with line drawing (inset) and core log site 039. The core site is shown on the seismic example and located in Figs 2 and 7. The twoway travel time in $\mathrm{ms}$ is labelled on the left side of the profile, and the core log shows altitude in $\mathrm{m}$. Subunits indicated on the line drawing. See Fig. 8 for legend.
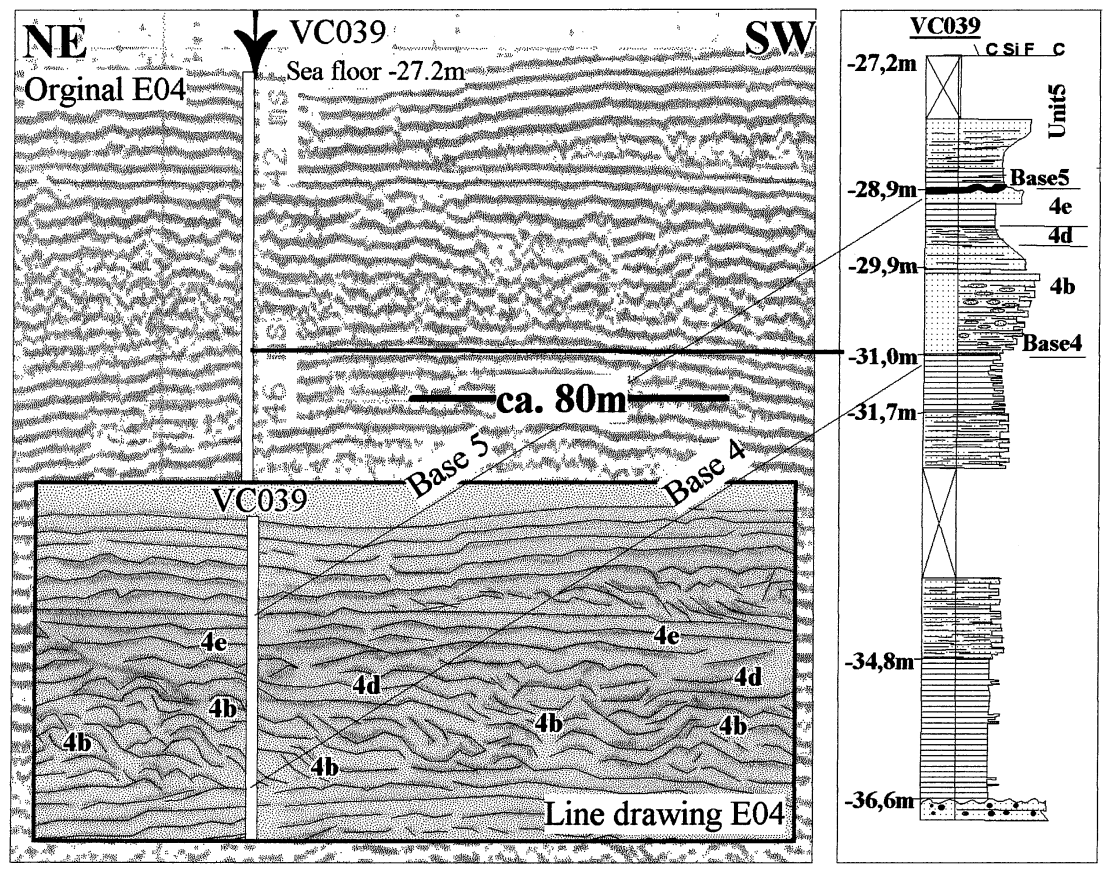

excluded (Figs 3-6). In the second stage, the line drawings were used to identify seismic facies (Table 2), and they formed the basis for the seismic stratigraphic interpretation (Figs 3-6). A selected part of the study area (Fig. 7) was then analysed in detail.

Fluvial architectural elements and a hierarchy of bounding surfaces (Miall, 1985, 1988) were used to correlate seismic units, subunits and seismic facies interpretations with fluvial lithofacies associations. Miall (1988) concluded that architectural elements of fluvial deposits can be ordered into a hierarchy of six bounding surfaces and that the fourth-order surfaces can be analogues to the clinoforms observable on seismic sections. The sixth-order surface (palaeovalley, fluvial units) is used in this study to separate unit 4 (Figs 7-9) from the underlying unit 3 and the overlying unit 5 . The fifth-order surface (major sheets) is used to divide subunits and related environmental changes (Figs 10-14). Well-developed fourth-order surfaces (downstream and lateral accretion elements) are used to support the interpretation of environmental conditions.

Vibrocoring was carried out with a 12-m Alpine 271 air-driven device (sample diameter $110 \mathrm{~mm}$ ).
Fig. 6. A $3 \cdot 5-\mathrm{kHz}$ pinger seismic profile with line drawing (inset) and core log site 045 . The core site is shown on the seismic profile and located in Figs 2, 7 and 8. The twoway travel time in $\mathrm{ms}$ is labelled on the left side of the profile, and the core log shows altitude in $\mathrm{m}$. Subunits indicated on the line drawing. See Fig. 8 for legend.
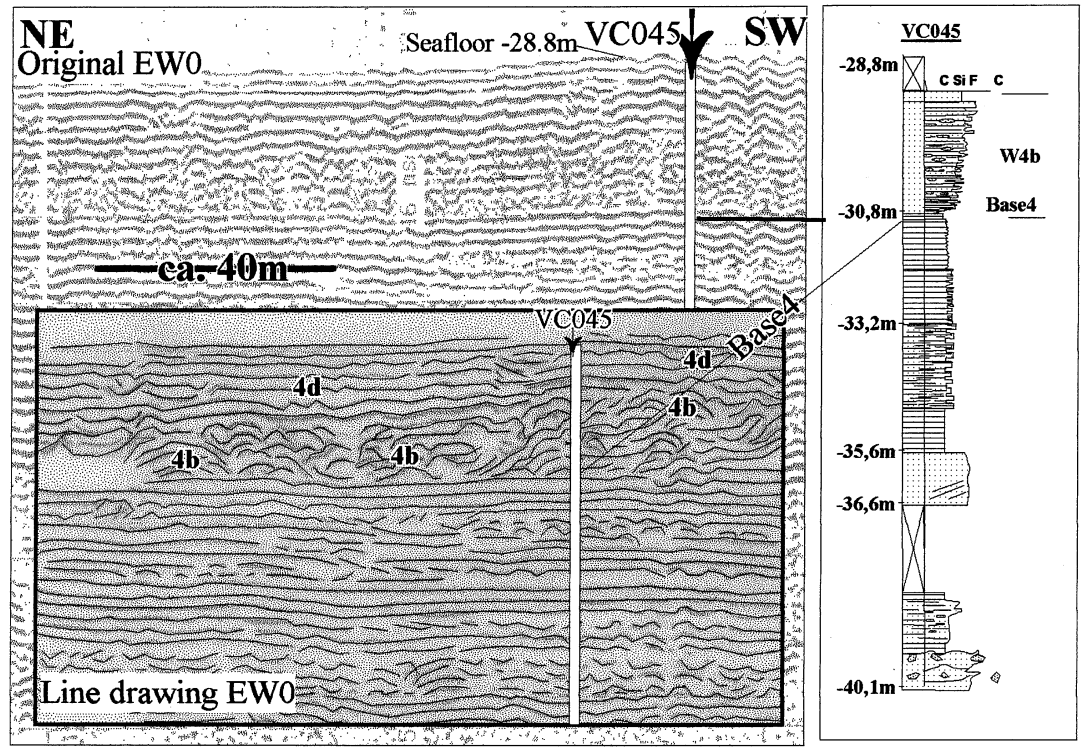

(c) 2002 International Association of Sedimentologists, Sedimentology, 49, 451-465 
Table 2. Summary of seismic facies in subunits and their related features.

\begin{tabular}{llllll}
\hline Subunit & Description of facies & Morphology & Size height (m)/width (m) & Lap-style & Orientation \\
\hline $4^{\mathrm{a}}$ & Oblique-parallel, reflection free & Sheet & $1 \cdot 5 / 2000$ & Dn, Te & N-S \\
$4^{\mathrm{b}}$ & Mound, oblique-tangential & Mound & $2 \cdot 5 / 500-1000$ & Dn, (Te) & NW-SE \\
$4^{\mathrm{c}}$ & Sigmoid-oblique, mound & Braided & $1 \cdot 5 / 2000$ & Dn, (Te, Tp) NW-SE & NW \\
$4^{\mathrm{d}}$ & Shingled, parallel, mound & Oxbow & $1 \cdot 5 / 500-1000$ & (Dn) & Nandom data \\
$4^{\mathrm{e}}$ & Parallel, shingled reflection free & Pool & $1 \cdot 5 / 200-1000$ & Random \\
\hline
\end{tabular}

Lap: Te, erosional truncation; Dn, downlap; Tp, toplap.

A total of 32 vibrocores were obtained from the study area. Several fine-grained lithologies were then analysed with X-ray imaging. Monitoring of water levels was made relative to DNN.GI (Danish normal zero) and recorded every $15 \mathrm{~min}$, and the vibrocores were levelled according to these records.

Seven ${ }^{14} \mathrm{C}$ dates (Table 3) were used to provide age control.

\section{RESULTS}

Analysis of seismic facies was limited to unit 4 (Figs 8 and 9). The sequence is located above unit 3 (which contains laminated silt and clay tentatively correlated to sequence 3 of Bennike \& Jensen, 1998) and below unit $5\left(<9 \cdot 0{ }^{14} \mathrm{C}\right.$ ka BP $)$. It ranges in altitude from $-32.5 \mathrm{~m}$ to $-24.5 \mathrm{~m}$ (Figs 7-9).

The base of unit 4 defines a wide U-shaped valley (Figs 7-9) with a steeper escarpment towards the south-west than towards the north- east. The horizontal central part of the valley has an altitude between $-29 \mathrm{~m}$ and $-32.5 \mathrm{~m}$ (Fig. 7). The plane parallel reflections in the underlying unit 3, which terminate at the base of unit 4, are typically truncated. Prominent elongate depressions in the central part of the valley floor are orientated north-west-south-east (Fig. 7). A narrow zone of high-amplitude coherent reflectors comprises the seismic image along the base of the unit. Mounds (i.e. positive-relief structures) are a common seismic facies that help to define the surface (Figs 4-6). The escarpments on both sides of the valley have characteristic terraces or step-like morphology (Figs 3, 8 and 9). Beneath the 'steps', characteristic reflections have high dip angles towards the north, north-east and east (Figs 2 and 3).

Facies analysis in a small portion of the study area (Figs 7 and 10-14) shows that unit 4 can be subdivided into five subunits (Table 2).

Subunit $4^{\mathrm{a}}$ (Fig. 10) fills the elongate depressions in the central parts of the valley (Fig. 7), below $-30 \mathrm{~m}$. The low-angle oblique-parallel

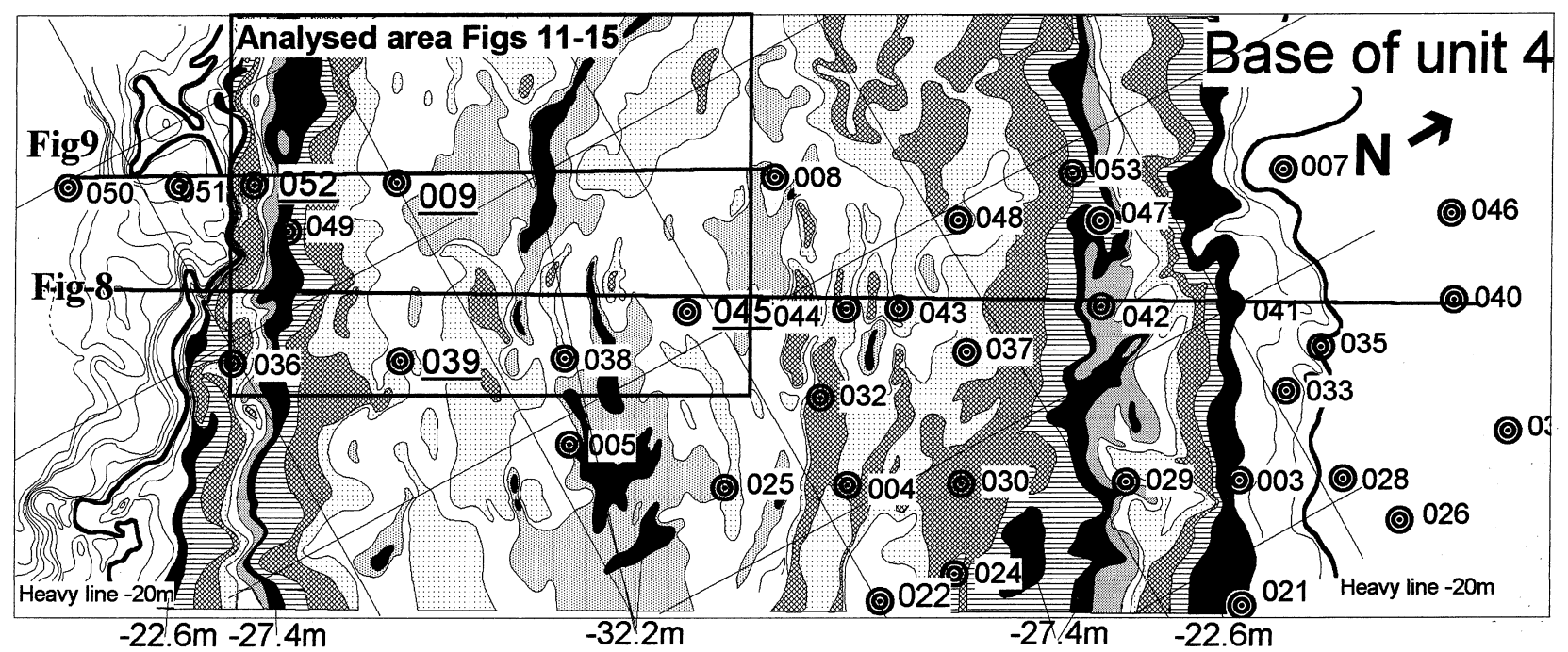

Fig. 7. Map of base of unit 4 showing vibrocore sites and 2-km cells of UTM grid. Contours indicate altitude at $0 \cdot 8-\mathrm{m}$ intervals: $>-32 \cdot 2 \mathrm{~m}$ for central basin black, $-27 \cdot 4$ to $-28 \cdot 2 \mathrm{~m}$ middle black and $-22 \cdot 6$ to $-23 \cdot 4 \mathrm{~m}$ for upper basin black. Inserted rectangle shows the location of selected analysed areas, the results of which are shown in Fig. 10-14. Locations of profiles in Figs 8 and 9 are also shown. 


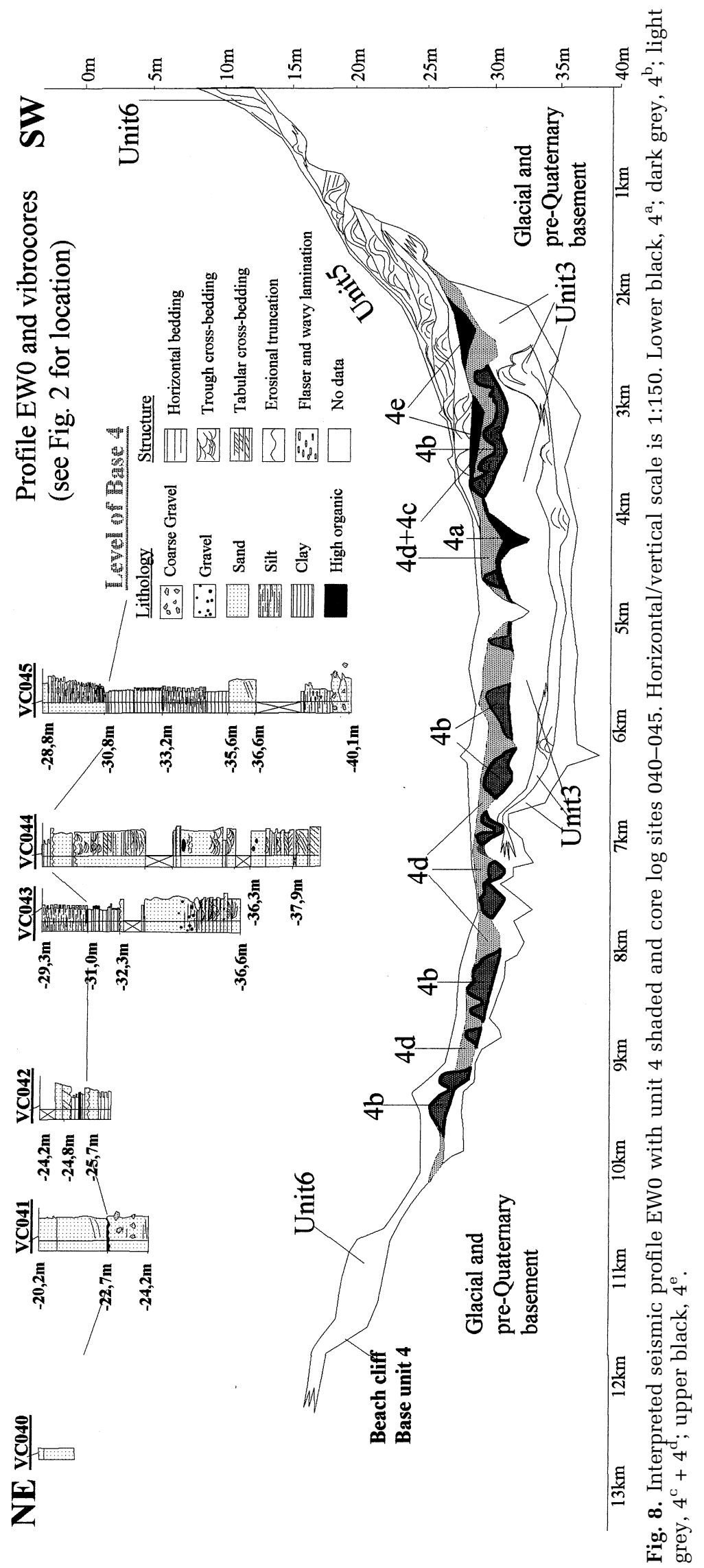




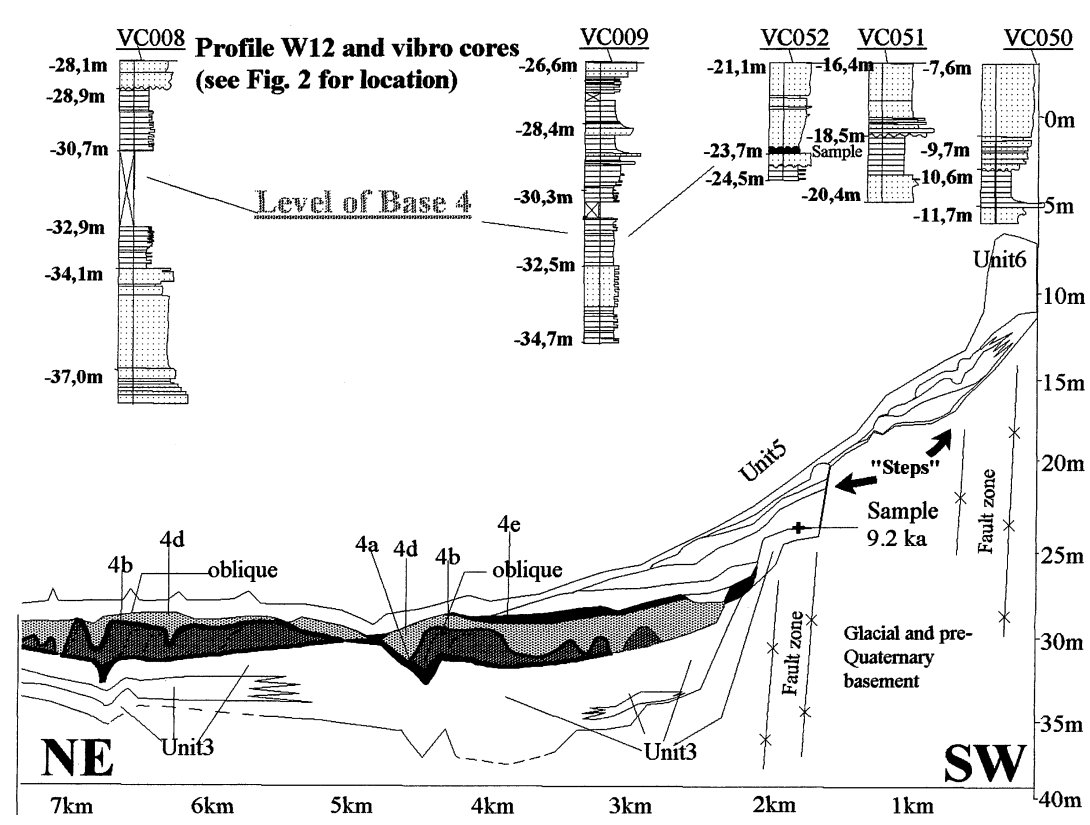

Fig. 9. Interpreted seismic profile W12 with unit 4 shaded and core log sites 008, 009, 050, 051 and 052. Horizontal/vertical scale is 1:150. See Fig. 8 for legend. seismic facies dips west and towards the depressions and amalgamates with reflection-free facies. No samples of this facies are available.

Subunit $4^{\mathrm{b}}$ (Figs 4-11) comprises mainly mound facies (Table 2); it is found in the central and north-eastern parts of the analysed area but is absent in a narrow 'channel' separating these two parts. Elongate depressions dissect this subunit locally. The altitude of the base ranges between $-32 \mathrm{~m}$ and $-24.5 \mathrm{~m}$, with the highest level along the north-east escarpment (Fig. 8). In the central portion, where the mound facies are covered along the northern side by subsequently deposited oblique facies (Fig. 9, Table 2), the subunit has a maximum thickness and volume. Bold arrows indicate the dip direction of the oblique reflections (Fig. 11), which show progradation towards the north-west. Near the southern escarpment, narrow ridges (<100 $\mathrm{m}$ wide) bend and are orientated north-west. Another moundoblique depositional centre is indicated immediately north-east of the analysed area (near core site 008; Fig. 7). Core sites 039 and 045 are located in the central portion of the mound fields. At these locations, reflections correspond to laminated, lenticular and wavy silty to fine sand beds, which coarsen upwards and contain few coarser grains. At core site 039, the beds are overlain by a massive fine sand bed that grades into silt (Figs 5 and 6), and the top of $4^{\mathrm{b}}$ truncates a $0 \cdot 1$ - to $0 \cdot 15$-m-thick bed with wavy to flaser structures. At core site 008, the seismic facies

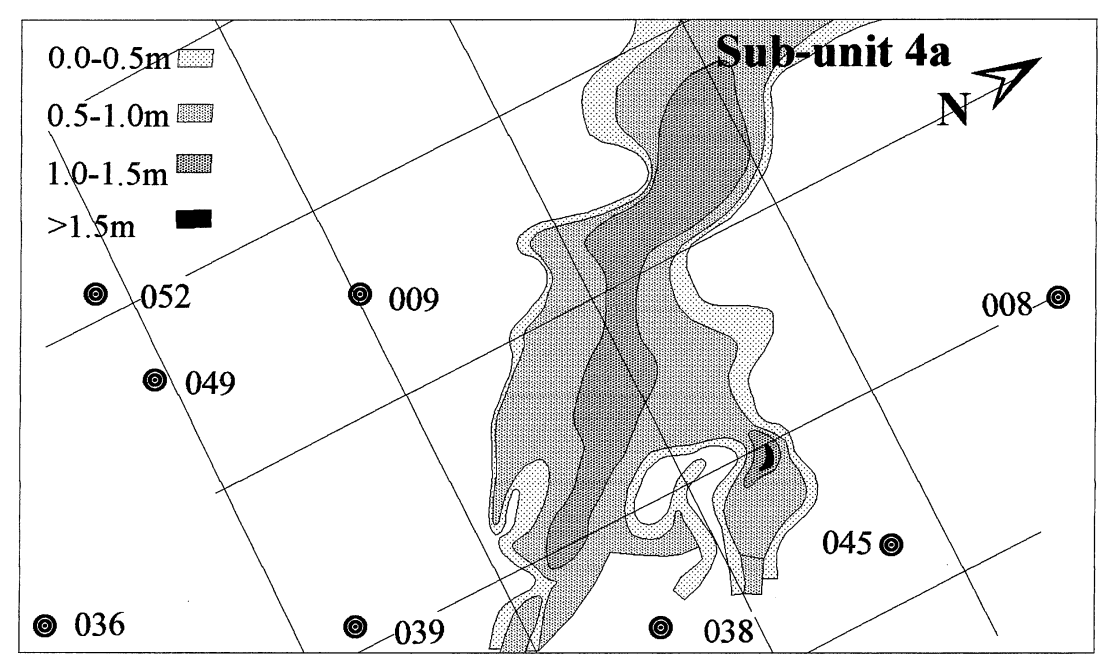

Fig. 10. Isopach map of subunit $4^{\mathrm{a}}$ and locations of vibrocores. UTM grid spacing is $1 \mathrm{~km}$. 
Fig. 11. Isopach map of subunit $4^{\mathrm{b}}$ and locations of vibrocores. Bold arrows indicate dip direction of interpreted fourth-order surfaces sensu Miall (1988). Thin arrows indicate dip direction of minor seismic surfaces. UTM grid spacing is $1 \mathrm{~km}$.

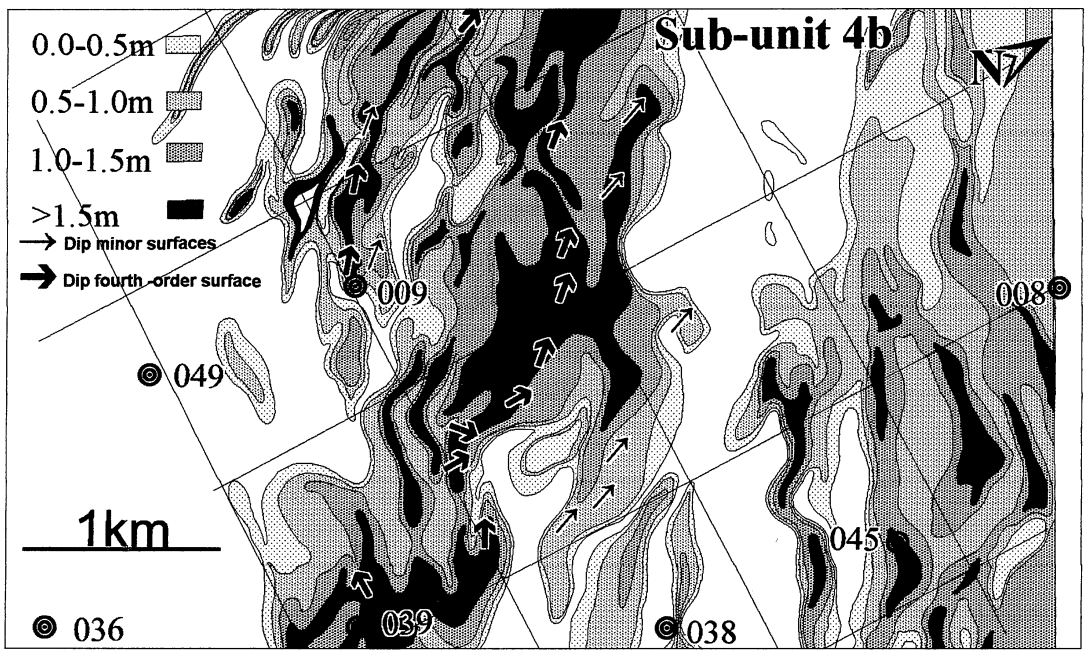

represent very fine, cross-laminated cycles of alternating silt and fine sand with thicknesses of 0.10-0.15 m. Core site 009 (Fig. 4) is located on the edge of a mound area (Fig. 11) and a coarsening-upward clay-silt bed, which has abundant thin silt and fine sand laminae, correlates with the mound facies in the seismic data.

Subunit $4^{\mathrm{C}}$ (Figs 4 and 12) has a characteristic sigmoid-(oblique) reflection pattern and is found in the south-eastern part of the analysed area, where it is located between mounds. A prominent elongate shape is typical of this 1500-m-wide deposit, which is oriented between north-west and north-north-west (Fig. 12). The single isolated forms are half as thick and wide as the underlying mounds. Core samples of $4^{\mathrm{C}}$ are not available.

Subunit $4^{\mathrm{d}}$ (Figs 4-6 and 13) completely covers the analysed area and overlies subunits $4^{\mathrm{a}-\mathrm{c}}$ and the base of unit 4 . The oxbow plan morphology of $4^{\mathrm{d}}$ is characteristic (Fig. 13). These random-orientated forms are $<2.0 \mathrm{~m}$ thick and typically 50 $200 \mathrm{~m}$ wide. The narrow belts where this subunit is absent tend to show meandering forms (Fig. 13). Core site 009 is located on the edge of one of the larger oxbow forms, and core samples show two fining-upward, coarse sand-clay cycles with thicknesses of $0 \cdot 2 \mathrm{~m}$ and $0 \cdot 1 \mathrm{~m}$, respectively, containing redeposited rootlets (Fig. 4). Core site 038 reveals clay with silt lenses or thin laminae of silt $(1.0 \mathrm{~m}$ thick), overlain by a silty bed $(0.4 \mathrm{~m}$ thick) in the centre of the oxbow forms. Core site 039 (Fig. 5) is located at the edge of a small, isolated $4^{\mathrm{d}}$ deposit and contains $<0.3 \mathrm{~m}$ of silt with organic material.

Subunit $4^{\mathrm{e}}$ (Figs 4 and 14) is found in the southwestern part of the analysed area overlying subunit $4^{\mathrm{d}}$. These deposits are either $50-200 \mathrm{~m}$ wide with oxbow morphology or $>500 \mathrm{~m}$ wide with a pool-like morphology. A channel-like
Fig. 12. Isopach map of subunit $4^{\mathrm{C}}$ and location of vibrocores. UTM grid spacing is $1 \mathrm{~km}$.

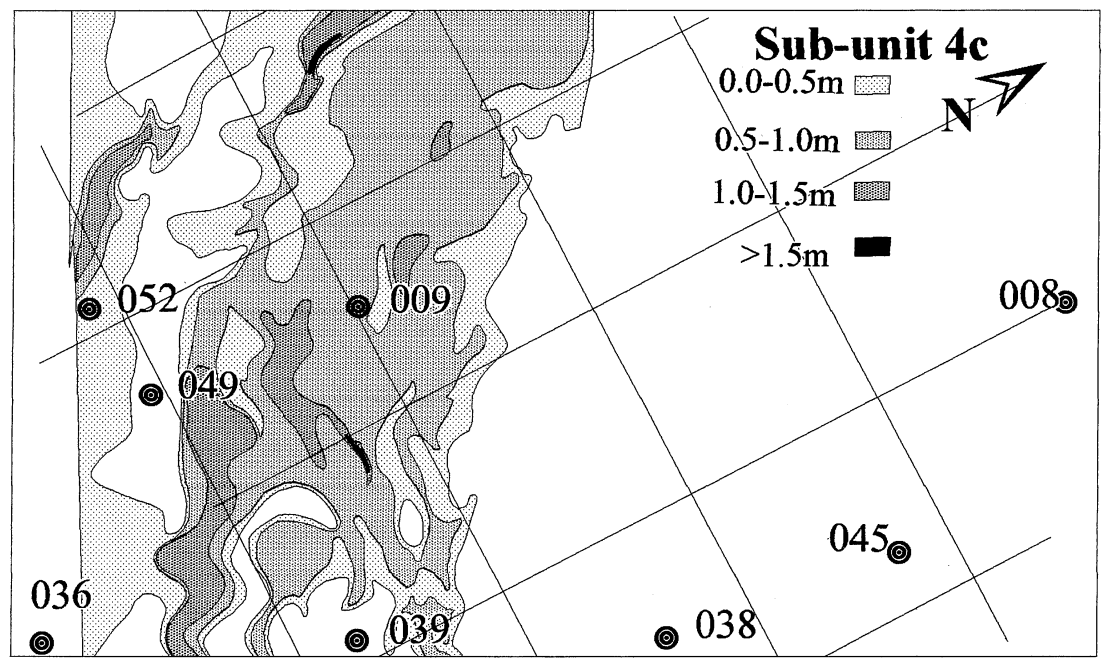

(c) 2002 International Association of Sedimentologists, Sedimentology, 49, 451-465 


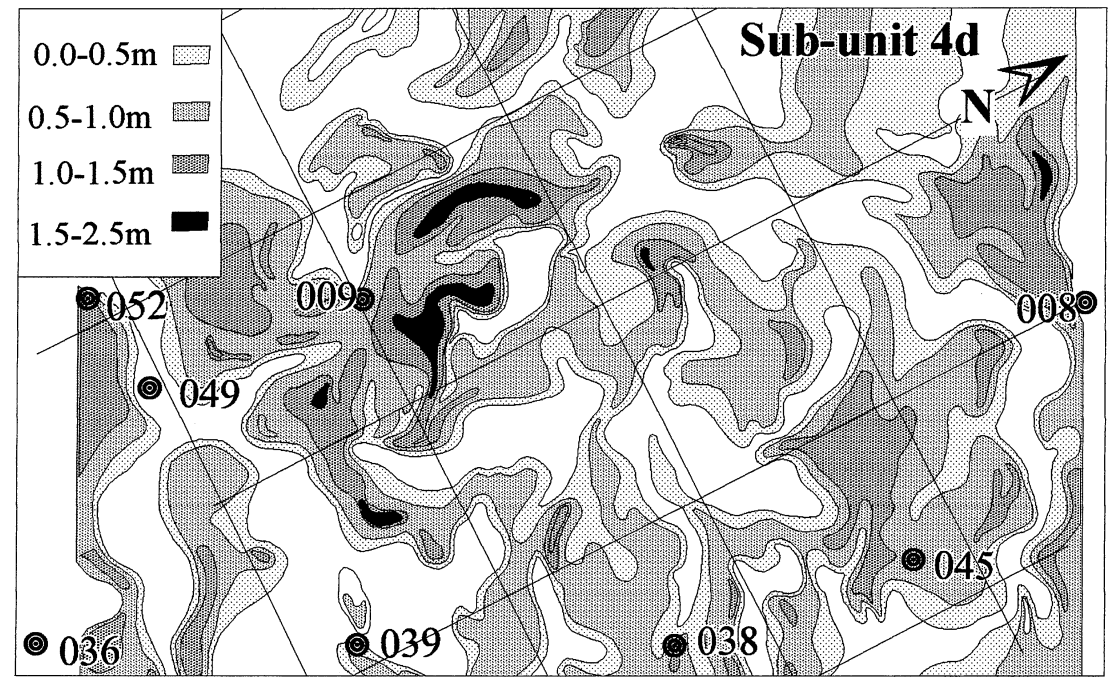

Fig. 13. Isopach map of subunit $4^{\mathrm{d}}$ and location of vibrocores. UTM grid spacing is $1 \mathrm{~km}$. deposit of $4^{\mathrm{e}}$ near the southern escarpment is more than $200 \mathrm{~m}$ wide. At core site 009, a finingupward silty clay bed $(0.5 \mathrm{~m}$ thick) with high organic content, including whole leaves, is located at $-29 \mathrm{~m}$ altitude, underlying a poorly sorted fine-to-medium sand layer $(0 \cdot 15 \mathrm{~m}$ thick) with plant remains. This layer is covered by a thin organic drift gyttja (0.005 m thick) (Fig. 4). Core site 039 is located on the edge of subunit $4^{\mathrm{e}}$ in which a maximum of $0.3 \mathrm{~m}$ of clay and an overlying sand bed are capped by a thin drift gyttja (Fig. 5).

Unit 5 (Figs 8 and 9) overlies unit 4 and contains marine bivalves at some levels. Its smooth base is marked by a series of high-amplitude reflectors easily recognized throughout the study area (Figs 4 and 5). A sandy unit 6 that downlaps on unit 5 and has the overall form of clinoforms is everywhere located above $-20 \mathrm{~m}$ altitude.
In unit 4, two radiocarbon ages from wood at $-25 \cdot 8$ to $25 \cdot 85 \mathrm{~m}$ altitude at site 036 (Table 3 ) both yielded an age of $9 \cdot 2{ }^{14} \mathrm{C}$ ka $\mathrm{BP}$, while dating of algae gyttja $0.5 \mathrm{~m}$ above the wood and on top of unit 4 yielded an age of $9 \cdot 6{ }^{14} \mathrm{C}$ ka BP. This implies reservoir problems for the gyttja, possibly caused by carbonates or, alternatively, it implies reworking. An age of $9 \cdot 6{ }^{14} \mathrm{C}$ ka $\mathrm{BP}$ was also obtained from a drift gyttja on top of unit 4 at site 049 , at an altitude of $-26 \cdot 1 \mathrm{~m}$, which is apparently the same age as the gyttja in site 036. These gyttjas are correlated to similar units at sites 009 and 039 , and the deposits are most likely younger than $9 \cdot 2{ }^{14} \mathrm{C}$ ka BP, as the remains of wood below the gyttja at site 036 give a maximum age; in this case, wood gives a more reliable age than the gyttjas. At site 052 , at an altitude of $-23.7 \mathrm{~m}$, another wood sample was dated to $9 \cdot 2{ }^{14} \mathrm{C}$ ka BP. Another piece of wood in drift gyttja, on top of

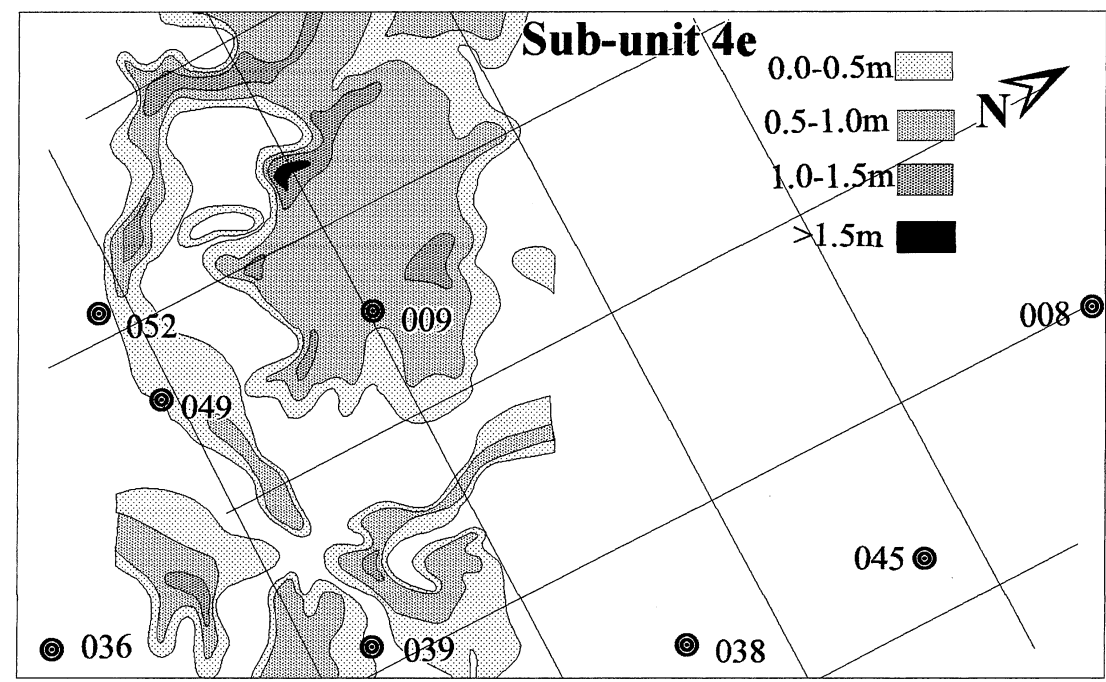

Fig. 14. Isopach map of subunit $4^{\mathrm{e}}$ and location of vibrocores. UTM grid spacing is $1 \mathrm{~km}$. 
Table 3 . Radiocarbon ages of samples from unit 4 in the Fehmarn Belt.

\begin{tabular}{lllllr}
\hline Core & Easting & Northing & b.s.l. & Type & ${ }^{14} \mathrm{C}$ ka BP \\
\hline 36 & $646183 \mathrm{~m}$ & $6043945 \mathrm{~m}$ & $25 \cdot 32 \mathrm{~m}$ & Gyttja & $9 \cdot 56 \mathrm{a}$ \\
36 & $646183 \mathrm{~m}$ & $6043945 \mathrm{~m}$ & $25 \cdot 80 \mathrm{~m}$ & Wood & $9 \cdot 22 \mathrm{a}$ \\
36 & $646183 \mathrm{~m}$ & $6043945 \mathrm{~m}$ & $25 \cdot 85 \mathrm{~m}$ & Wood & $9 \cdot 20 \mathrm{a}$ \\
42 & $649445 \mathrm{~m}$ & $6051025 \mathrm{~m}$ & $25 \cdot 80 \mathrm{~m}$ & Wood & $10 \cdot 77 \mathrm{a}$ \\
49 & $645364 \mathrm{~m}$ & $6044957 \mathrm{~m}$ & $26 \cdot 10 \mathrm{~m}$ & Gyttja & $9 \cdot 62 \mathrm{a}$ \\
49 & $645364 \mathrm{~m}$ & $6044957 \mathrm{~m}$ & $26 \cdot 10 \mathrm{~m}$ & Gyttja & $9 \cdot 71 \mathrm{a}$ \\
52 & $644860 \mathrm{~m}$ & $6044891 \mathrm{~m}$ & $23 \cdot 70 \mathrm{~m}$ & Wood & $9 \cdot 26 \mathrm{a}$ \\
\hline
\end{tabular}

laminated sand/silt at $-25.8 \mathrm{~m}$ altitude in core 042 , was found to have an age of $10 \cdot 8{ }^{14} \mathrm{C}$ ka BP.

\section{INTERPRETATION AND DISCUSSION}

\section{Depositional environments}

The base of unit 4, which forms a sixth-order surface, sensu Miall (1988), is generally smooth and erodes into underlying deposits (Fig. 7). Initially, the water level in the area could have been as high as $-19 \mathrm{~m}$ in altitude, limited by the general consensus that the local final BIL(f) and $\mathrm{AL}$ levels did not exceed this limit before their drainage $c \cdot 10 \cdot 3{ }^{14} \mathrm{C}$ ka $\mathrm{BP}$ and $9 \cdot 0{ }^{14} \mathrm{C}$ ka $\mathrm{BP}$ respectively (Björck, 1995; Bennike \& Jensen, 1998; Jensen et al., 1999). At this limit, the water-filled profile across the valley would have been $90000 \mathrm{~m}^{2}$ (Figs 7 and 8). Fossil cliffs at the north-east escarpment of the valley, which could result from coastal erosion, indicate a water table at that level (Fig. 8).

Although no significant single high-amplitude reflections divide subunits $4^{\mathrm{a}-\mathrm{e}}$, the mapped facies changes represent changes in process and environment (Table 2). The interfaces are inferred to be fifth-order surfaces, sensu Miall (1988), when considered in the context of fluvial deposits.

The external sheet morphology of subunit $4^{\mathrm{a}}$, the internal low-amplitude and reflection-free facies, the truncated and tabular nature of the oblique internal reflections and the location at the lowest stratigraphic level and altitude at the base of unit 4 all indicate sand that was deposited with a relatively high energy compared with the subsequent subunit $4^{\mathrm{b}}$. This interpretation of the seismic facies is supported by acoustically transparent to low-amplitude, lens or sheet facies observed nearby in another unit (the same data set) and corresponding to a sandy lithology in cores.
Subunit $4^{\mathrm{b}}$, deposited below $-24 \mathrm{~m}$ altitude, covers subunit $4^{\mathrm{a}}$ in places (Figs 8, 10 and 11), and the prominent internal reflections between the mounds, interpreted as fourth-order surfaces (Miall, 1988), show downstream accretion towards the north-west. These characteristics, together with the elongate and nearly straight planform (Fig. 11), represent sediments deposited from a westward-directed unidirectional flow. The lack of gravel beds and organic material and the presence of coarsening-upward laminated, lenticular and wavy beds of silt and fine sand with cross-lamination at core sites 039 and 045 (Figs 5 and 6) indicate increasing flow velocity as well as falling water level over the mounds during deposition. The distribution of mounds over the $>8000-m$-wide profile and between the base of unit 4 and subunits $4^{\mathrm{c}-\mathrm{e}}$ (Fig. 8) indicates synchronous deposition over a fairly short time span throughout the entire valley floor.

The confined subunit $4^{\mathrm{c}}$, with an elongate braided pattern, is located below $-26 \cdot 0 \mathrm{~m}$ altitude (Fig. 12) and is separated from the underlying mounds by a change in acoustic facies that indicates a fifth-order surface. In the channelled area to the south-west, the depositional style between the mounds, characteristic throughout the 8000-m-wide profile (Fig. 8), indicates that the water table fell to below $-24 \mathrm{~m}$ altitude and that the water was channelled between the mounds. The area of the flow profile was thus reduced to $45000 \mathrm{~m}^{2}$ (Figs 8 and 12). The characteristic onlap sigmoidal reflection pattern, the coarsening-upward lithology of clay, silt and fine sand and the small-scale morphology indicate not only that flow power fell relative to $4^{\mathrm{b}}$, but also that dunes still formed. Above $4^{\mathrm{C}}$, a fifth-order surface divides the elongate deposit from $4^{\mathrm{d}}$ deposits, but it also seems possible that unit $4^{\mathrm{C}}$ in the south-west (Fig. 12) could have been deposited simultaneously with $4^{\mathrm{d}}$ (Fig. 13) further to the north-east where $4^{\mathrm{C}}$ deposits are absent. 
Subunit $4^{\mathrm{d}}$, which has a characteristic oxbow morphology, is the result of a meandering or braided stream that developed when flow power fell, and when the main stream was confined to the channels between the mounds below an altitude of $-25.0 \mathrm{~m}$ (Fig. 8) according to the level of the oxbow structures. Sand-clay cycles on the outside edge (core site 009) and clay-silt cycles with high organic debris content in the centre of the oxbow structure (core site 038) indicate gradual infill of the meander arcs with general fining-upward lithology. The active area (Fig. 8) was further reduced to well below $30000 \mathrm{~m}^{2}$ as a result of the sediment infill. Background discharge must have been a dominant factor in the flow style, as all the Baltic discharge was possibly channelled through the Great Belt. Annual fluctuations resulted in occasional overbank sedimentation at the fringes of the stream (Fig. 13).

Further reduction in flow power, caused by reduction in gradient and downcutting of the stream in the central valley (Figs 8 and 9), resulted in cut-off of former active flow areas, which then became larger pools (Fig. 14). These pools became traps for clay sedimentation during occasional high-water stands. Finally, thin gyttja deposits settled in calm pools above $-29 \mathrm{~m}$ altitude. The succession of subunits $4^{\mathrm{a}-\mathrm{e}}$ represents a fluvial environment changing from a highenergy stream with rapidly falling water level to a low-energy stream. Winn et al. (1986) suggested that a terrace in Kiel Bay, west of the study area at $-27 \mathrm{~m}$ altitude, corresponds to a Great Belt threshold control of the lake level after the regression in the $\mathrm{AL}$ at $-28 \mathrm{~m}$ altitude. This time and level correlate well with the results of the present study.

\section{Tectonics}

Winn et al. (1986) concluded that the only significant Holocene differential subsidence in Kiel Bay (Fig. 1) are local effects, resulting from salt movement, and that no regional effect is observed between Lübeck, east of the study area, and the Kiel Bay area. The till beneath the irregular base of unit 4 at core sites 036, 045 and 051 is rich in both pebbles and cobbles, but the absence of a residual pebbly unit at the base of unit 4 is characteristic. No seismic evidence of a unit representing a coarser residual from a winnowed till is present, as would be expected if the irregular base were the result of extensive erosion of the till. It is therefore possible that tectonic movement influenced the late and post-glacial depositional history in the study area. Furthermore, fault activity, located directly beneath the south-western escarpment (Figs 2 and 3), may be partly responsible for the dislocated and irregular base of the deposits (Figs 3, 8 and 9). One explanation for the faulting could be that a prominent dome structure, which appears $c$. $10 \mathrm{~km}$ north-east of the analysed area (Fig. 1), arose as the result of salt movement (Danish Ministry of Transport, Bundesministerium für Verkehr, 1996). Chalk is found at $-50 \mathrm{~m}$ altitude at the summit of this dome, but $>100 \mathrm{~m}$ beneath the study area.

\section{Timing}

The base of unit 4 can be traced throughout the valley and is correlated with a reflector seen in the widely spaced GEUS profiles covering the region (Fig. 1). From the ${ }^{14} \mathrm{C}$ dating on wood, it is obvious that the age of the unit 4/unit 5 boundary is younger than $9 \cdot 2{ }^{14} \mathrm{C}$ ka BP (Table 3). Based on a ${ }^{14} \mathrm{C}$ date from rootlets at a location $c .10 \mathrm{~km}$ west of the study area, Bennike \& Jensen (1998) dated a sequence $\mathrm{W} 4$ above the regional seismic surface, which constitutes the base of unit 4 , to $9 \cdot 4{ }^{14} \mathrm{C}$ ka BP (Fig. 1). They suggested that this age may be anomalously old because of reworking. Jensen et al. (1997) and Bennike \& Jensen (1998) suggested that their seismic unit W4 represents local lakes and bogs. In the study area, a local drowned bog at the fringes of the stream, where the water velocity was lowest, is evident at core site 036 and is dated to $9 \cdot 2{ }^{14} \mathrm{C}$ ka BP. The bog water provided protection from turbulence and a trap for fine-grained sediments, which allowed peat to be preserved.

No samples have been taken from subunit $4^{\mathrm{a}}$, and there are no dated samples from subunit $4^{\mathrm{b}}$. The changing sedimentary character between subunits $4^{\mathrm{b}}$ and $4^{\mathrm{C}-\mathrm{e}}$ is marked by lack of plant remains in subunit $4^{\mathrm{b}}$. If subunit $4^{\mathrm{b}}$ is of late glacial age (e.g. from deglaciation), interface $4^{\mathrm{b}} /$ $4^{\mathrm{C}-\mathrm{e}}$ would represent a hiatus of several thousand years. Such a hiatus would be expected to show up as a marked reflector considering the differences in the lithology between the subunits. However, the results show a regional reflector at the base of unit 4 , whereas the interface $4^{\mathrm{b}} / 4^{\mathrm{c}-\mathrm{e}}$ is only recognized by seismic facies analyses. Furthermore, the sedimentary facies is in good agreement with the development of the environments interpreted from the seismic facies analysis of the subunits, e.g. increasing organic content with decreasing flow power. The succession $4^{\mathrm{a}}$ to 
$4^{\mathrm{e}}$ is therefore interpreted to have been deposited more or less continuously.

Compared with the channel systems that can be followed from the study area into the Great Belt (Krogh, 1965; Lemke et al., 2000) and into southern Kattegat (Novak \& Björck, 1998), the infilled acoustic facies association in southern Kattegat has some common characteristics with the association found in the Fehmarn Belt. Both depositional systems have examples of high-altitude deposition in the stream profile (Fig. 8), and both systems gradually become more confined to channels with an overall evolution from straight to more sinuous and random-orientated forms (Figs 10 and 14, Table 2). On the other hand, the lithology indicates a much lower energy in the wide valley of the Fehmarn Belt during maximum stream velocity compared with the peak flow in the Kattegat (Novak \& Björck, 1998). The similarities in addition to the common channel system suggest that, as in the southern Kattegat, unit 4 is the result of rapid drainage, and that the two seismic facies associations could be the result of the same peak flow. Lemke et al. (2000) suggested that late and post-glacial deposits in the narrow ribbon channels consist of fine-grained sediments, and they have been dated between $9 \cdot 2$ and $9 \cdot 0{ }^{14} \mathrm{C}$ ka BP (Lemke et al., 2001). The age of the basal sand-gravel subunit below the finegrained sediments in the narrow channel is not well known, but the results of the present study support the view that they may represent part of the fluvial event discussed. It can be concluded that the drainage event was initiated when lake level in the study area was high. The two known high water level situations that could have fed the fluvial event within the determined time frame (Table 3), allowing for the possibility that the dated rootlets in GEUS 564003 could have been found in situ, are the BIL(f) stage at $10 \cdot 3{ }^{14} \mathrm{C}$ ka BP and the AL first stage at $9 \cdot 0{ }^{14} \mathrm{C}$ ka BP.

\section{The drainage event}

A sudden shift from calm lacustrine conditions to a unidirectional flow environment developed in the study area (Fig. 15) when the threshold collapsed somewhere downstream between the Fehmarn Belt and the Kattegat (Fig. 1). Water velocity upstream of the threshold, i.e. within the

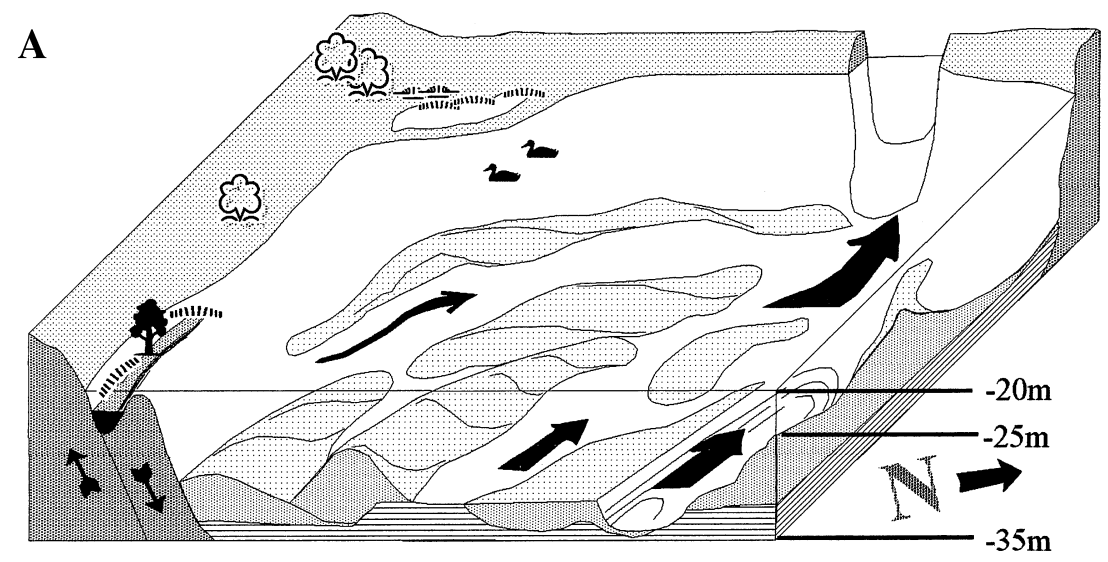

Fig. 15. Model showing two stages of the drainage of the dammed lake in the Fehmarn Belt area. Faulting in the escarpment is indicated by small arrows and water flow by large arrows. (A) Water level at maximum altitude of $-20 \mathrm{~m}$. Rapid transgression has submerged a bog at the fringes in the south-east. Flow power is at its maximum at this stage, leading to the formation of elongate and straight bars in the deep central areas. (B) Water level lowered to $-25 \mathrm{~m}$. The stream energy is reduced and the channels are developed.

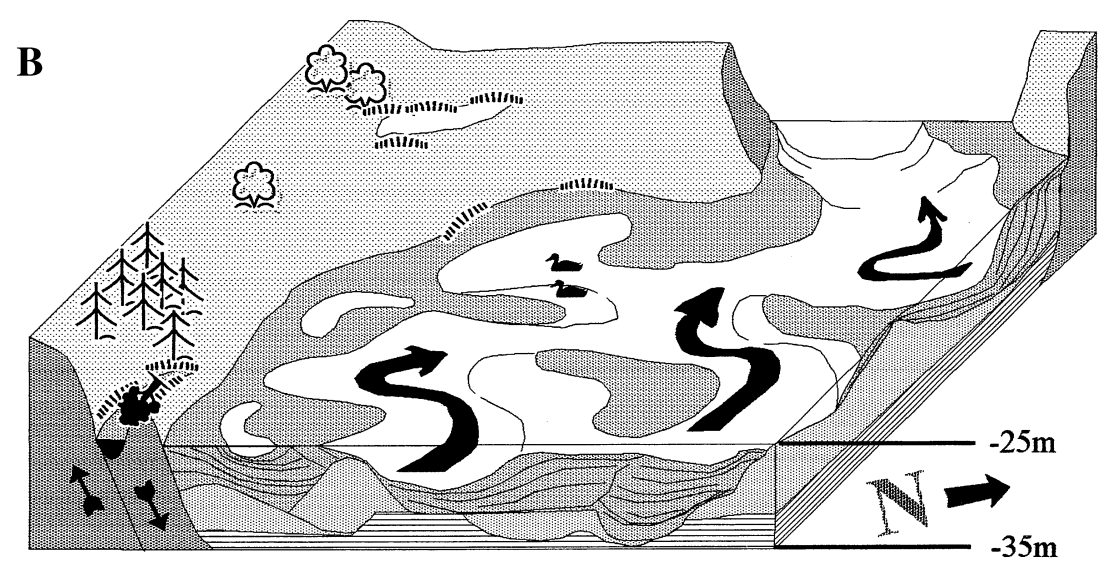

(C) 2002 International Association of Sedimentologists, Sedimentology, 49, 451-465 
lake, would have been highest above the deepest central areas and where the now filled lowest part was deepened by erosion. (Figs 7, 10 and 15). At the fringes at higher levels, water velocities approached zero. The gradient between the lake and sea levels was gradually reduced and was governed by threshold erosion and water discharge until an equilibrium was reached. The normal freshwater discharge from the Baltic area preserved a minimum gradient, and a steady-state situation was established in the Fehmarn Belt with a local base level near $-25 \mathrm{~m}$ altitude.

\section{CONCLUSIONS}

1 Westward drainage of a dammed lake took place between $10 \cdot 3$ and $9 \cdot 0{ }^{14} \mathrm{C}$ ka $\mathrm{BP}$ in the Fehmarn Belt. The seismic facies association reveals maximum flow power at the initial stage of the drainage, after which water discharge and level fell rapidly until a normal background discharge from the Baltic Sea area became the dominating factor in the flow style.

2 Fault activity in the area could have been one of more causes that opened a pathway to the initiation of the rapid drainage from the lake.

3 The seismic stratigraphic succession reveals a high-resolution record of sediments. In particular, the stepwise uncovering of the morphology and internal structures of the subunits, preserved in high-resolution seismic facies associations, has proved to be a useful tool in modelling the dynamic development of the near sea-floor environment.

\section{ACKNOWLEDGEMENTS}

The data were placed at our disposal by the Danish Trafikministeriet. Earlier versions of the manuscript benefited greatly from constructive criticism by the referees, Dr Mike Talbot, Bergen, Dr Milan Beres, Lausanne, and Dr Wolfram Lemke, Rostock.

\section{REFERENCES}

Bennike, O. and Jensen, J.B. (1998) Late- and postglacial shore level changes in the southwestern Baltic Sea. Bull. Geol. Soc. Denmark, 45, 27-38.

Bennike, O., Jensen, J.B. and Lemke, W. (1997) Macrofossil and geochronological studies of submarine deposits from the southwesten Baltic. Sver. Geol. Unders., 86, 11-14.
Bennike, O., Jensen, J.B. and Lemke, W. (1998) Fauna and flora in submarine early Holocene lake-marl deposits from the south-western Baltic Sea. Holocene, 8, 353-358.

Björck, S. (1979) Late Weichselian Stratigraphy of Blekinge, SE Sweden, and Water Level Changes in the Baltic Ice Lake. PhD Thesis. Department of Quaternary Geology, University of Lund.

Björck, S. (1987) An answer to Ancylus enigma?- Presentation of a working hypothesis. Geol. Fören. Stockh. Förh., 109, 171-176.

Björck, S. (1995) A review of the history of the Baltic Sea, 13.0 ka-8.0 ka. Quatern. Int., 27, 19-40.

Björck, S. and Digerfeld, G. (1986) Late Weichselian-Early Holocene shore displacement west of Mt. Billingen, within the Middle Swedish end moraine zone. Boreas, 15, 1-18.

Björck, S. and Möller, P. (1987) Late Weichselian environmental history in south-eastern Sweden during the deglaciation of the Scandinavian Ice Sheet. Quatern. Res., 28, $1-37$.

Danish Ministry of Transport, Bundesministerium für Verkehr (1996) Fehmarn Belt Feasibility Study, Coast-To-Coast Investigations. Danish Geotechnical Institute.

Eronen, M. (1983) Late Weichselian and Holocene shore displacement in Finland. In: Shoreline and Isostasy (Eds D.E. Smith and A.G. Dawson), Inst. Br. Geogr. Spec. Publ., 16, 183-207.

Eronen, M., Ristaniemin, O. and Lange, D. (1990) Analysis of a sediment core from the Mecklenburg Bay, with a discussion on the early Holocene history of the southern Baltic Sea. Geol. Fören. Stockh. Förh., 12, 1-8.

Jensen, J.B., Kuijpers, A. and Lemke, W. (1996) Geologisk kort over Danmark, 1:200000. Kortblad Femer Bælt-Arkona Basinet, Sen-Kvartære sedimenter. Dan. Geol. Unders., 52, 1-16.

Jensen, J.B., Bennike, O., Witkowski, A., Lemke, W. and Kuijpers, A. (1997) The Baltic Ice Lake in the south-western Baltic: sequence-, chrono- and biostratigraphy. Boreas, 26, 217-236.

Jensen, J.B., Bennike, O., Witkowski, A., Lemke, W. and Kuijpers, A. (1999) Early Holocene history of the south-western Baltic Sea: the Ancylus Lake stage. Boreas, 28, 437-353.

Krogh, H. (1965) On the post-glacial development of the Great Belt. Baltica, 2, 47-60.

Lagerlund, E. and Houmark-Nielsen, M. (1993) Timing and pattern of the last deglaciation in the Kattegat region, southwest Scandinavia. Boreas, 22, 337-347.

Lemke, W. and Kuijpers, A. (1995) Late Pleistocene and early Holocene palaeogeography of the Darss Sill area, southwestern Baltic. Quatern. Int., 27, 73-81.

Lemke, W., Kuijpers, A., Hoffmann, G., Milkert, D. and Atzler, R. (1994) The Darss Sill hydrographic threshold in south-western Baltic: Late Quaternary geology and recent sediment dynamic. Cont. Shelf Res., 14, 847-870.

Lemke, W., Jensen, J.B., Bennike, O. and Witkowski, A. (1997) Sequence stratigraphy of submarine Late Pleistocene and Holocene deposits in Mecklenburg Bay, south-western Baltic. Sver. Geol. Unders., 86, 117-122.

Lemke, W., Jensen, J.B., Endler, R., Witkowski, A. and Kuijpers, A. (2000) Paleogeographical implications of bathymetric threshold in Western Baltic Sea. In: Environmental Changes in Fennoscandia During the Late Quaternary (Ed. P. Sandgren), p. 126. LUNDQUA Report 37. Department of Quaternary Geology, Lund University, Lund.

Lemke, W., Jensen, J.B., Endler, R., Witkowski, A. and Kuijpers, A. (2001) Hydrographic threshold in the western 
Baltic Sea: Late Quaternary geology and the Dana River concept. Mar. Geol., 176, 191-201.

Lundqvist, J. (1987) Glaciodynamics of the Younger Dryas marginal zone in Scandinavia. Geogr. Ann., 69A, 305-319.

Miall, A.D. (1985) Architectural-element analysis: a new method of facies analysis to fluvial deposits. Earth-Sci. Rev., 22, 261-308.

Miall, A.D. (1988) Architectural elements and bounding surfaces in fluvial deposits: anatomy of the Kayenta formation (Lower Jurassic), Southwest Colorado. Sed. Geol., 55, 233-262.

Mitchum, R.M., Jr, Vail, P.R. and Sangree, J.B. (1977) Seismic stratigraphy and global changes of sea level, part 6: Stratigraphic interpretation of seismic reflection patterns in depositional sequences. AAPG Mem., 26, 117-135.

Mörner, N.-A. (1969) Eustasy and climatic changes during the last 15000 years. Geol. Mijnbouw, 48, 389-399.

Novak, B. and Björck, S. (1998) Marine seismic studies in southern Kattegat, with special emphasis on longitudinal bars and their possible relationship to the drainage of the Ancylus Lake. Geol. Fören. Stockh. Förh., 120, 297-306.

Novak, B. and Pedersen, G.K. (2000) Sedimentology, seismic facies and stratigraphy of a Holocene spit-platform complex interpreted from high-resolution shallow seismic, Lysegrund, southern Kattegat, Denmark. Mar. Geol., 162, 317-335.
Novak, B. and Stoker, M. (2001) Late Weichselian glacimarine depositional processes in the southern Skagerrak revealed by high-resolution acoustic facies analysis. Mar. Geol., 178, 115-133.

von Post, L. (1929) Svea, Göta och Dana älvar. Ymer, 49, 1-33.

Ristaniemi, O. and Glückert, G. (1987) The Ancylus transgression in the area of Espoo - The First Saulpasselkä, southern Finland. Bull. Geol. Soc. Finland, 59, 45-69.

Svensson, N.-O. (1989) Late Weichselian and Early Holocene Shore Displacement in the Central Baltic, based on Stratigraphical and Morphological Records from Eastern Smaland and Gotland, Sweden. LUNDQUA Thesis 25. Department of Quaternary Geology, Lund University, Lund.

Svensson, N.-O. (1991) Late Weichselian and early Holocene shore displacement in the central Baltic Sea. Quatern. Int., 9, 7-26.

Ter-Borch, N. (1987) Structural Map of Top Chalk Group. The Danish National Forest and Nature Agency and Danish Oil and Gas Company.

Winn, K., Averdick, F.-R., Erlenkeuser, H. and Werner, F. (1986) Holocene sea-level rise in the western Baltic and the question of isostatic subsidence. Meyniana, 38, 60-81.

Manuscript received 30 March 2001; revision accepted 22 November 2001. 